Article

\title{
An Imperfect Alliance: Feminism and Contemporary Female Buddhist Monasticisms
}

\author{
Amy Paris Langenberg \\ Religious Studies, Eckerd College, St. Petersburg, FL 33711, USA; langenap@eckerd.edu
}

Received: 9 May 2018; Accepted: 11 June 2018; Published: 14 June 2018

check for updates

\begin{abstract}
This essay lays the elaborate textile of feminist discourse alongside the equally rich fabric of contemporary female Buddhist monasticisms, taking note of places the latter has pulled threads from the former, but also pointing out the ways in which female monastics lead agentive, creative, and sometimes rebellious female lives that in subtle and not so subtle ways resist the label "feminist," or contribute a new motif or fiber to the feminist weave. Case study reports on two innovative Buddhist female communities in Malaysia and Nepal, chosen because they offer examples of innovations within the context of Buddhist female monasticism that are interestingly complex as examples of Buddhist feminist consciousness, will serve to make visible a few particular female Buddhist monastic perspectives. Respectfully called in as interlocutors and cotheorizers, the monastic persons described here offer religious perspectives on norm-following, agency, and coalition-building that expand the feminist frame.
\end{abstract}

Keywords: liberal feminism; poststructural feminism; postcolonial feminism; female Buddhist monasticism; engaged Buddhism; Buddhism; Buddhist monasticism; Buddhist feminism; Judith Butler; Saba Mahmood

\section{Introduction ${ }^{1}$}

The Buddhist order of female ascetics was founded, according to the vinaya (Buddhist canonical texts that report the early history of the Buddhist order and its discipline), ${ }^{2}$ after Mahāprajāpatī Gautamī and her kinswomen requested ordination from the Buddha. ${ }^{3}$ Mahāprajāpatī Gautamī was the sister of the Buddha's mother, Māyā, and raised him from infancy after Māyā's postpartum death. The Pāli Vinaya narrative mentions that Gautamī's Śăkya companions had been abandoned when their husbands and sons left home to join the Buddhist order. Gautamī herself had been recently widowed (Ohnuma 2006, p. 863). All versions record the Buddha's ambivalent response to Gautamī's request. In several, he employs the metaphor of devastating crop loss to convey his sense that disaster would result from the presence of women in the Buddhist order (Heirman 2001, p. 282). For instance, in the Mahāsāinghika-lokottaravāda Bhikṣuṇ̄ Vinaya, the Lord warns Ānanda that, "Mother Gautamī should not

1 The author would like to express her gratitude to Darlene Juschke, Susanne Mrozik, and the anonymous reviewers for their important comments. It goes without saying that she feels deeply indebted to Venerable Tenzin Dadon, Venerable Karma Tashi Choedron, and Venerable Metteyya Sakyaputta for so generously and openly sharing with her their time, communities, and conversation.

2 The story of the founding of the woman's order is the common property of the various Buddhist schools. Versions of the story contain the same major elements but differ somewhat in certain details, in which elements are emphasized, and in their rhetoric. For comparative studies of different versions, see (Heirman 2001 and Ohnuma 2006). For an argument about how to interpret these accounts historically, see (Anālayo 2008).

3 Those trained in Indic languages will notice an inconsistent use of diacritics in this article. I have chosen to spell names of places and people as they typically appear online and in their own materials rather than use diacritics in a technically correct manner throughout. So, for instance, I use Gotami Vihara instead of Gotamī Vihāra and Guruma Bodhi Sakyadhita instead of Gurumā Bodhi Sakyadhītā 
wish for the admission of women into the order or for their ordination as nuns ... Indeed, Annanda, it would be just as though a disease known as 'red rust' were to fall on a ripe field of sugar cane. Just as that would be a great defilement to the field of sugar cane, so it would be a great defilement to the teaching of the Buddha were mother Gautami allowed to be initiated into his order and become a nun" (Strong 2008, p. 65). The reasons for the Buddha's ambivalence regarding the nuns' order are not clearly and explicitly stated within traditional narratives, but the implication is he worried the laity would not respect and give generously to a mendicant order that included women. The Buddha does eventually acquiesce to Gautamī's request, but only on condition that nuns be legally and ritually subordinate to monks.

Historically, Buddhist institutions have been structured around a strict gender binary, despite a doctrinal commitment to nonessentialist views of the self across Buddhist traditions. In many contemporary female Buddhist orders, nuns are dependent on male teachers for ordination, teachings, and the legal resolution of disputes within their communities. ${ }^{4}$ They may also suffer from a lack of status in the eyes of lay patrons and a reduced access to resources compared to monks. ${ }^{5}$ Buddhist law also forbids from joining the Buddhist orders individuals who, biologically or in terms of gender performance and sexuality, fall outside of the categories of "male" and "female" (Cabezón 2017, pp. 373-85; Gyatso 2003). ${ }^{6}$ Contemporary Buddhists have directly challenged gender hierarchical and gender binary norms in Buddhism on several fronts. In America and Europe, nonmonastic LGBTQI groups have created inclusive communities in which a keen awareness of the complexity of gender and sexual identity and the social suffering of sexual minorities is incorporated into discussions of the dharma (Gleig 2012). Within transnational Buddhism, a distinct feminist consciousness has emerged since the late 1980's. This Buddhist feminist consciousness has found an organizational home in Sakyadhita International Association of Buddhist Women. ${ }^{7}$

Monastic Buddhist women, especially those connected to Sakyadhita, have focused a significant portion of their energies on the goal of achieving higher ordination for all Buddhist women, a ritual status that is currently unavailable to women in the majority of Theravāda and Tibetan Buddhist

4 Buddhist feminist scholars have focused, in particular, on the role of the eight "rules to be respected" (gurudharmas/garudhammas) in creating and maintaining gender hierarchy within the Buddhist sangha (community). These were the rules said to be promulgated by the Buddha prior to his acceptance of the first women into the Buddhist order. They include a rule requiring nuns, no matter how senior, to bow before and show respect to any monk, no matter how junior, and another allowing monks to criticize the behavior of nuns but forbidding nuns to criticize monks. They also establish dual ordination as the norm for nuns and a special two-year "waiting period" for nuns, called sikșamāna, prior to the taking of bhiksunī (full) vows. Their exact legal status is a subject of debate (Kawanami 2007; articles in Mohr and Tsedroen 2010). In 2001, the Taiwanese nun, Chao Hwei, participated in a public protest in which she assisted in tearing up a copy of the eight rules, declaring the advent of "Mahāprajāpatī's Second Revolution" (DeVido 2010, p. 107). In some contemporary monastic contexts, these rules are honored, in others ignored.

5 See, for instance, (Gutschow 2004; Kawanami 2007; Levine and Gellner 2005; Sonam 2017). However, Korean nuns operate independent educational and training institutions (Park 2011). In Taiwan, nuns outnumber monks, run thriving organizations such as Ciji, are educated at the highest levels, and are highly regarded for their social service work (DeVido 2010). Taiwanese nuns have been instrumental in the revival of the bhikkhuni orders in Thailand, Sri Lanka, and now the Tibetan Karma Kagyu lineage. Many women in the mae chii orders of Thailand regard their status as preferable to the bhikkhuni orders because they enjoy greater autonomy from the male sangha (Falk 2007, p. 250) Bartholomeusz makes a similar point regarding Sri Lankan dasasilmātās (Bartholomeusz 1994, pp. 136-37).

6 It is not necessarily the case, of course, that transsexual or non-gender conforming individuals have never participated in Buddhist monastic life, which is vastly diverse. Japanese Buddhism, for instance, includes the tradition of the chigo, a class of adolescent males installed at Japanese temples as sexual and spiritual companions for monks (Atkins 2008; Faure 1998). While celibacy is the rule, some have argued that Buddhist monastic discipline is less severe regarding same-sex sexual behavior than heterosexual behavior (Cabezón 1993; 2017, p. 333).

7 Sakyadhita convenes meetings every two years, usually in Asian locations. The most recent Sakyadhita conference (Hong Kong, June 2017) included inter alia presentations with the following titles: "Feminism and the Everyday Lives of Nuns and Monks in Kinnaur" (Linda LaMacchia); "Himalayan Feminism" (Sonam Choden); "Bhikkhunī Ordination and Digital Activism" (Anna Halafoff and Emma Tomalin); "Buddhist Feminism and Crosscultural Cognitive Dissonance" (Brianna Kathryn Morseth); "Buddhism, Equality, and Feminism: Embodied Practices (Sat Yen Lai); "The Next Obstacles for Buddhist-Feminist Scholar-Practitioners" (Hsiao-Lan Hu). See (Halafoff and Rajkobal 2015; Koppedrayer and Fenn 2008; and Mrozik 2009 for analyses of the Sakyadhita movement). 
contexts (Mrozik 2009). ${ }^{8}$ The ordination issue is of crucial concern as it directly impacts women's ability to achieve a ritual and legal status within Buddhist monastic institutions that is on par with what is available to men. In the absence of this ability, Buddhist monastic women may find it more difficult to overcome institutional subordination, powerlessness even within their female communities, poverty, poor self-regard, impoverished educational opportunities, and limited access to Buddhist teachings and training from qualified teachers. As Susanne Mrozik, Nirmala Salgado, and Horoko Kawanami have observed, each separately, however, bhikkhuni revival is controversial, even among nuns (Kawanami 2007; Mrozik 2009; Salgado 2013). Many female monastics in Southeast Asia, for instance, wish to gain greater access to patronage, education, and government assistance through means other than the universal availability of higher ordination.

Like Mahāprajāpatī Gautamī and her kinswomen, many Buddhist women and girls, and their advocates, attempt to address gendered limitations and vulnerability within the institutional structures and ethical formations of celibate Buddhist monasticism, despite its lack of gender parity. For some monastic women, including the Nepali Theravāda nuns studied by Sarah Levine and David Gellner, admission into the monastic life is a potent form of social liberation from the compulsion to marry and mother children (Levine and Gellner 2005, p. 273). For these women, liberal feminist notions such as "false consciousness" or "bargaining with the patriarchy" are clearly inadequate for making sense of their Buddhist motivations and lives. For others, the egalitarian feminism or, as one scholar puts it, "justice feminism," (Hu 2017) of liberal Buddhist feminists like Rita Gross and Karma Lekshe Tsomo has been useful for articulating the oppression they experience and the institutional changes they would like to see. ${ }^{9}$ The intentional and agentive manner in which yet other female and pro-female Buddhist monastics occupy gender conservative Buddhist norms resonates better, on the other hand, with postmodern understandings of self and modalities of resistance mapped in the poststructural interventions of Judith Butler, Lila Abu-Lughod and others. Still, other dimensions of female Buddhist monastic attitudes towards gender, sexuality, and human sociality may fall outside of the bounds of any known feminist discourse, identifiable as parafeminist ${ }^{10}$ or even anti-feminist (Mrozik 2009; Salgado 2013). For many of the Burmese thilashin (members of alternative female renunciant orders) studied by Hiroko Kawanami, for instance, the Buddhist path, with its emphasis on humility, moral purity, and service, stands in opposition to feminism (Kawanami 2007, p. 238).

This essay lays the elaborate textile of feminist discourse alongside the equally rich fabric of contemporary female Buddhist monasticisms, taking note of places the latter has pulled threads from the former, but also pointing out the ways in which female monastics lead agentive, creative, and sometimes rebellious female lives that in subtle and not so subtle ways resist the label "feminist," or contribute a new motif or fiber to the feminist weave. Of course, feminism is far from univocal, and one has only to step into a Sakyadhita conference to understand that the linguistic, social, cultural, institutional, and sectarian landscape of female Buddhist monasticisms is also diverse. One task of this essay is to outline a feminist curriculum or syllabus that resonates with contemporary female monastic thought and practice. In addition, case study reports on two innovative Buddhist female communities will serve to make visible a few particular female (and pro-female) Buddhist monastic perspectives. Respectfully called in as interlocutors and cotheorizers, these monastic persons offer perspectives on norm-following, agency, and coalition-building that augment, come along side, disrupt, or sometimes oppose existing feminist traditions of thought. To stay with the metaphor, this essay regards them as

8 The Karmapa, one of the most important lamas in the Kagyu lineage of Tibetan Buddhism, has recently begun to lay the groundwork for the eventual ordination of bhikșuniss in his lineage.

9 See, for instance, (Choden 2017; Lai 2017; Sonam 2017; Tsomo 2010).

10 I invented the term "parafeminist", which I am defining as an ideology that runs alongside, has much in common with, but is not in the same cultural and intellectual stream as, feminism, in imitation of the term "parachurch". I have since learned that the term "parafeminist" had already been coined a decade ago by the important feminist art critic, Amelia Jones, as part of her critique of universalizing notions of gender in second-wave feminism. I employ the term in a more general and literal sense here, not in the highly theorized and particular sense that Jones uses it. 
honored speakers in the feminist classroom who have been invited to contribute new curricula to an evolving and exploratory feminist syllabus.

The first of the two case studies considered here is a small fluid community consisting of two dynamic and well-educated Vajrayāna nuns, Venerables Tenzin Dadon and Karma Tashi Choedron, and their lay supporters and students. Tenzin and Karma live in Kuala Lumpur, Malaysia and are regular participants in Sakyadhita conferences. The second of the case studies is a small female community, Peace Grove Institute, made up of approximately twenty-six young female monastics, aged seven to twenty-seven, and located in the Buddhist pilgrimage town of Lumbini, Nepal. These young girls and women have been initiated within and follow the teachings of the Theravāda school of Buddhism. The Peace Grove nuns and their teacher, Metteyya Sakyaputta, are not closely connected to Sakyadhita. While I have come to know the Peace Grove community after leading several college groups on a service-oriented study abroad course in Lumbini, any detailed knowledge I have of the history of this community was acquired through conversations with Venerable Metteyya, not the girls themselves. ${ }^{11}$ Venerables Tenzin and Karma have been conversation partners over a number of years so, of the two examples, the Malaysian case includes more in the way of subjective and experiential perspectives. ${ }^{12}$ It is important to note that neither of these examples represents the monastic mainstream. ${ }^{13}$ I chose them because they offer examples of innovations within the context of Buddhist female monasticism that are interestingly complex as instances of Buddhist feminist, parafeminist, and sometimes anti-feminist consciousness.

Some may regard the issues raised here regarding feminism and the non-West as already settled. Indeed, many postcolonial feminists have pointed out the problematic nature of a universalizing feminist discourse. Some have indexed how the liberal feminist conflation of female agency with feminist political activism or "the voluntarism of the female subject" occludes the female every day and presets the terms of what can be acknowledged as agency (McNay 2015, p. 3). Patricia Jefferey, for instance, draws attention to the fact that, "in various low-profile ways, [South Asian] women critique their subordination and resist the controls over them-in personal reminiscences or songs, in sabotage and cheating. The husband treated like a lord or deity to his face maybe derided behind his back or given excessively salty meals" (Jefferey [1998] 2001, p. 466). ${ }^{14}$ Saba Mahmood has produced an important (if controversial) critique of what she terms "liberal secular feminist" analyses of feminist agency, calling for an interrogation of the European Enlightenment's sovereign self, an ontology that she argues underlies the liberal feminist call for resisting norms (Mahmood 2005). ${ }^{15}$ Other postcolonial

11 My grant-supported ethnographic study of Peace Grove is ongoing.

12 While I have known Venerables Tenzin and Karma since 2011, much of the detailed information included here was gathered during interviews and conversations that took place in Kuala Lumpur in July of 2017.

13 It is possible that some members of the transnational Buddhist community might be critical of the unorthodox nature of the communities described here. For instance, at the 12th Sakyadhita conference in Bangkok, Bhikkhuni Dhammananda, an important figure in the restoration of the bhikkhuni lineage in Thailand, rigorously criticized the various ways in which the Theravāda nuns' community in Nepal falls short of the disciplinary and ritual norms laid out in canonical texts, blaming herself and transnational nuns' community for not providing more help and guidance. For instance, most Nepali Theravāda nuns wear the pink robes of the Burmese nuns' tradition, a color disallowed in the vinaya. Most, according to Dhammananda, do not have the monastic training to properly perform the sanghakamma (prescribed community rituals, such as vassa). See (Dhammananda 2011). It is also important to note, however, that, the practices and behaviors considered compulsory for monastic life vary from locale to locale in the broad landscape of female Buddhist renunciant practice.

14 Abu-Lughod (1990) describes similar sorts of microresistances by Bedouin women in Egypt, but warns against "misattributing to them forms of consciousness or politics that are not part of their experience-something like a feminist consciousness or feminist politics" (p. 47). Sharon Suh tells a story from her research with Korean American Buddhist women, but is seems less concerned about differentiating feminism and resistance: "I remember one night sitting and watching women make tortillas to feed everybody after [a chanting] service. As they rolled their tortillas, one of the laywomen said, 'You know the Buddha teaches us that we should look at all beings as if they are the Buddha. Okay, so incorporating teachings of Buddha nature. But, when I look at my husband, I can't imagine that the Buddha would look as bad as that.' That was a very funny moment, but it was also a very telling moment. It shows that our assumptions about the compliance or submissiveness of these women are wrong" (Gregory and Mrozik 2008, p. 73).

15 See (McNay 2015) for a critical reading of Mahmood. McNay calls Mahmood's take down of liberal feminist notions of agency "exaggerated". 
feminists, of which Chandra Mohanty (2003) is an influential example, argue that Western feminisms have often found what Edward Said would call a "surrogate" and "underground self" (Said 1978, p. 3) in the so-called "third-world woman." In contrast to the putative liberated first-world feminist woman, she is constructed in feminist discourse as wholly dependent and under the thumb of marriage, religion, and poverty. Mohanty (2003) and others have also called attention to the way in which claiming a feminist political identity can place non-Western activist women in a precarious position with respect to their own social and political contexts, drawing the criticism that they are inauthentic, disloyal, and unduly influenced by an ethnocentric West that knows nothing of local values and conditions (Agarwal 1994; Lai 2017, p. 188). Finally, postcolonial feminists are keenly aware of the ways in which Western feminism has often failed to interrogate the intellectual, economic, and political privilege of the colonizing West even while protesting patriarchal power differentials (Agarwal 1994; Jefferey [1998] 2001; Moallem [1999] 2001; Mohanty 2003; Suh 2008).

The problematic nature of a universalizing global feminism has also been raised in relationship to Buddhism in particular (Gyatso 2010; Hu 2017; Lai 2017; Mrozik 2009; Salgado 2013). Susanne Mrozik (2009) describes the "troubling conflation of the terms 'international, 'western,' and 'feminist" in the context of debates about the higher ordination of women (p. 372). At a 2007 conference on the ordination issue convened by the Dalai Lama's office, a senior Tibetan monk complained that the debate about higher ordination for women amounted to an importation of Western values to the East. ${ }^{16}$ As Mrozik reports, some of the female monastics present also "strongly objected to the fact that conference participants frequently framed women's access to ordination in terms of gender discrimination and equality. They insisted, together with the sole ethnic Tibetan nun on the program, that they were not concerned with their status as women, but with completing their monastic educations and becoming qualified Dharma teachers" (Mrozik 2009, p. 372; see also Gyatso 2010, pp. 10-11). ${ }^{17}$ Informed by the work of Mohanty, Mahmood, and other post-colonial scholars, Nirmala Salgado has critiqued liberal feminist categories misapplied in the case of Sri Lankan dasasilmātās ("ten precept mothers," members of alternative renunciant orders for women). Salgado's work, which is based on fieldwork conducted over a number of years, looks granularly at the various day-to-day material and political concerns of her subjects. One of her conclusions is that most of her subjects, if they ever consider it at all, are not likely to understand the issue of higher ordination for women to hinge on issues like freedom from patriarchal control or the equality of women. Furthermore, she argues, unlike their feminist interpreters, most dasasilmātās prefer to understand their "problems" with housing, resources, pressure from monks, or conflicts with neighbors in relationship to the canonical Buddhist notion of $d u k k h a$ (suffering) and their search for nibbāna (liberation from rebirth), rather than their oppression as women (Salgado 2013, p. 2$){ }^{18}$

16 Kawanami (2007) describes a similar set of views among sangha higher ups in Burma. Some introduce a political motive, asserting that the bhikkhuni revival is backed by "agitators in the international community who [are] primarily intent on causing unrest inside Burma" (p. 232).

17 Linda LaMacchia (2017) records similar attitudes among the Kinnaur nuns she studies. One proclaimed, "We are not feminists, especially given the recent changes in Tibetan Buddhism allowing nuns to do what only monks had done before: to study philosophy, debate, and earn the geshe degree" (p. 7). In a 2010 essay, another Tibetan Buddhist nun, Lobsang Dechen, writes: "It is a commonly held view that Tibetan nuns are not interested in receiving bhiksuni ordination ... This is a misconception ... Our interest in receiving bhiksuni ordination is not driven by a concern for our status as women but by a wish to work most effectively toward liberation from cyclic existence for the benefit of all beings" (Dechen 2010 , pp. 208-9). In a conversation with Sharon Suh and bell hooks about American Buddhism and feminism at Smith College, Karma Lekshe Tsomo commented that "many [Buddhist women] do not use the word 'feminism,' especially in Asian and Asian American Buddhist communities. Even in the non-Asian Buddhist communities, I do not find very many women defining themselves as feminist, although I believe most of them are" (Gregory and Mrozik 2008, p. 74).

18 Karma Lekshe Tsomo, one of the founders of Sakyadhita, is highly critical of Salgado's postcolonial analysis in her review of her book. For instance, she writes, "If nuns cannot afford bus fare to study Buddhism, this is not simply an academic question or a case of 'narrative disjunction'; it is a very real problem that nuns would like to solve. Questioning the social and institutional structures that enforce the nuns' overt and internal subordination to the monks may be both wise and ethical, regardless of what passport one holds" (Tsomo 2015, p. 7). 
It is possible, therefore, to argue that the specter of the secular liberal feminist, unable to conceive of a "third world" religious woman as agentive or liberated, is, at this point, a straw woman, existing merely in scholarly discourse, set up only to be taken back down. Indeed, most feminist scholars of Buddhism are now well schooled in the postcolonial perspectives of Mohanty, Mahmood, Abu-Lughod, and Salgado. I do meet many real, live, adamantly secular feminists among the younger scholars I encounter in the undergraduate classroom, however, and I hope this essay may be useful to them in offering a fuller picture of the complicated relationship between feminism and contemporary female Buddhist monasticism. The principle argument in this essay is not, however, that Western feminists should remove their liberal secular gaze from the robed forms of Asian monastic women once and for all. Indeed, as Janet Gyatso observes, "it is far too Orientalist and nearsighted to continue to insist that feminism is merely a Western concern in which traditional women around the world do not also have a stake" (Gyatso 2010, p. 12). Rather, this essay seeks to partner with monastic women and men in understanding overlaps and disjunctures between feminism and contemporary Buddhist monasticism, as well as moments of what one might metaphorically call "parallel play". In particular, it seeks to explore how female monastics and their advocates stretch existing feminist traditions of social innovation and female empowerment, and the ways in which feminism, in all of its historical and philosophical complexity, supports, illuminates, or threatens their female or pro-female Buddhist consciousness in return.

\section{Innovative Female Buddhist Monasticisms: Malaysia}

While ethnically Bhutanese and Indian, and committed to a Tibetan tradition of monastic Buddhism, Venerables Tenzin Dadon ${ }^{19}$ and Karma Tashi Choedron live, teach, practice, and sometimes work in Kuala Lumpur, Malaysia. Buddhism in Malaysia is notably nonsectarian. The Chinese, Sinhala, Thai, Burmese, and Vajrayāna Buddhist communities all maintain temples, centers, and organizations and they are keenly aware, as Jeffrey Samuels puts it, of the "desire and need to work together" (Samuels 2017, p. 15). This perceived need for Buddhist unity is related to Buddhists' minority status in a Muslim majority country, which they have experienced as a political vulnerability, especially after the ethnically motivated riots of 1969. Their work of collaboration is furthered by a number of pan-Malaysian Buddhist organizations, both sectarian and nonsectarian, that coordinate events, put leadership around the same table, and provide a context for dialogue. ${ }^{20}$ Women have generally played a supporting role in these mostly lay-led organizations (Hea 2008).

Female monastics from all Buddhist traditions are informally linked by a network of personal connections and relationships in Malaysia. While the Chinese nuns' sangha (monastic community) has been relatively well supported in Malaysia and is reported to be larger than the Chinese monks' sangha (Terk 2008, p. 128), Theravāda and Vajrayāna nuns in Malaysia report financial vulnerability and a lack of institutional support. As of 2013, for instance, there were only fourteen Malaysian Vajrayāna Buddhist nuns, and seven of those had chosen to reside outside of Malaysia for purposes of education and practice (Choedron 2013, p. 223). The Gotami Vihara Society was established in 2012 to aid Buddhist female renunciants in Malaysia and Singapore. While its mission statement does not specify a sectarian affiliation, it is primarily focused on the welfare of Theravāda nuns in Malaysia. In addition to hosting dharma talks and retreats lead by female monastics, and celebrating International Bhikkhunī Day yearly, the Gotami Vihara Society has participated in the organization of three Theravāda Sāmaṇerī Novitiate programs, the latest of which is to be held in June 2018.

Malaysian Vajrayāna nuns support themselves in a variety of ways. Some survive on cash donations offered at teachings and prayer services. Others work in their family business or take outside

19 Tenzin Dadon is her preferred name, given at ordination. Tenzin has published and received degrees and awards under the name Sonam Wangmo, which she continues to use.

20 For example, the Malaysian Buddhist Association, the Vajrayana Buddhist Council of Malaysia, the Theravada Buddhist Council of Malaysia, the Youth Buddhist Association of Malaysia, and the Buddhist Gem Fellowship (Samuels 2017). 
employment. For instance, one runs a noodle business, another worked for a time as a fashion designer, and another teaches kindergarten. Several Malaysian nuns run social service initiatives, including youth centers, children's homes, medical clinics, and animal rescue (Choedron 2013, pp. 224-26). At the 2013 Sakyadhita conference, Karma concluded her presentation on the "Buddha's Lone Rangers" of Malaysia (its Vajrayāna nuns), by suggesting that Malaysian Buddhist organizations could be more proactive in reaching out to nuns, and expressing the desire for a Vajrayāna organization similar to the Gotami Vihara Society to advocate for them (Choedron 2013, p. 227).

Venerables Tenzin Dadon and Karma Tashi Choedron live together with their rescued cats in a quiet Kuala Lumpur apartment owned by Karma. Venerable Tenzin is from Bhutan. She was ordained as a novice nun in 1993 at the age of sixteen and left Bhutan six years later to study Buddhism at Jamyang Choeling Nunnery (established by the American Buddhist nun Karma Lekshe Tsomo) outside of Dharamsala, India. Tenzin now holds a 2009 M.A. in Buddhist Studies from Delhi University and a second M.A. in Buddhist Studies from the International Buddhist College in Southern Thailand, earned in 2016. She is also a newly minted Ph.D. in Women's and Gender Studies, University of Malaya. Tenzin is a published scholar ${ }^{21}$ and is admired as a leader in the international Buddhist women's community. In 2012, she received the Outstanding Woman in Buddhism Award, an honor created to mark Buddhist women's accomplishments on the occasion of the United Nation's International Women's Day.

Venerable Karma had won the same award two years earlier (2010) for her work in the area of Buddhism, animal welfare, and conservation. Venerable Karma was raised in the Sikh community in Malaysia. She is ethnically South Asian and not from a Buddhist family. She earned a Ph.D. in environmental sociology in 2008. She, like Venerable Tenzin, also recently earned an M.A. in Buddhist Studies from the International Buddhist College, Thailand. She was ordained in 2009 at the age of thirty-four. In an interview broadcast by the Lotus Communication Network, she describes the arising of her sudden and unexpected aspiration to become a nun when, as a stressed layperson plagued by existential questions about the purpose of life, she signed onto a short meditation retreat in Thailand:

After learning dependent origination, something happened in my mind. On the fifth day [of the course], I really, from the bottom of my heart, considered myself a Buddhist. I was not very religious and I was anti-establishment also. I didn't think that religion was a source of solace. I thought it was a source of the worst problems. But by the end of the retreat, my mind became very soft and very subtle and I suddenly sprang up this aspiration that "May I be able to spend my days and nights in meditation." ... I made aspiration prayers day and night for seven days: "May I become a nun." 22

Seven years later, Karma was ordained in Nepal as a śrāmanerī, a novice Buddhist nun, by Khenchen Thrangu Rinpoche. Karma's description of her mental attitude before conceiving an aspiration to renounce expresses well the lines of tension that exist between "anti-establishment" feminist sensibilities that regard religion as oppressive and female monastic aspirations that see in the Buddhist path something "soft," and "subtle," a truth that is deeply heart-felt and freeing.

While formal Buddhist discipline (vinaya) does not allow monks and nuns to work for wages for laypeople, even now, Karma occasionally dons laypersons' clothing, wraps her shaved head in a scarf, and takes environmental consulting jobs for pay. ${ }^{23}$ She is also a part time lecturer in Political Science at the University of Nottingham, Malaysia. These periods of employment are necessary, as lay donations are not generally sufficient to meet needs. As Karma noted in her 2013 Sakyadhita presentation, though

21 Sonam and Juli (2016); (Sonam and Tashi Choedron forthcoming).

22 Interview with Pattama Vilaileot, Lotus Communication Network. Published 2017. https://www.youtube.com/watch?v= vxQQr2ta9dI (accessed on 7 April 2018).

23 Trained as an environmental sociologist, Karma conducted social impact assessments, and forestry and oil palm audits prior to ordination (Choedron 2013, p. 225). 
lay interest in Vajrayāna Buddhism is on the rise in Malaysia, and while Malaysian lay Buddhists do not generally prefer monks to nuns, no formal organization currently exists to provide support, resources, and organizational structure to the small, scattered, Malaysian Vajrayāna nuns' community. ${ }^{24}$

Venerable Karma is older in years but Venerable Tenzin is older in monastic terms. She is considered by Karma to be the senior of the two of them. Moreover, Tenzin has more formal monastic training than Karma. From her side, Karma is confident, charismatic, and street smart. Tenzin and Karma have formed a close partnership, living in the Kuala Lumpur apartment Karma owns, pooling their financial resources, and building their religious careers together. Their approach to the monastic life is highly intentional. Rather than rising up through the ranks of an already established monastic institution, Tenzin and Karma have built a presence as female Buddhist teachers and engaged community leaders incrementally and entrepreneurially.

While they are well connected to prominent teachers and important communities inside and outside of Malaysia, Tenzin and Karma are not formally attached to any particular monastery. This is mainly because Malaysia lacks sangha and residential facilities for nuns are nonexistent. When questioned about why she doesn't leave Malaysia and seek a systematic dharma education or go into retreat in India or Nepal, Karma's answer is that "The sangha is needed in every country and India and Nepal have lots of them. Malaysians need the sangha, too, so why should we leave just because we struggle to survive here?" (Choedron 2013, p. 227). ${ }^{25}$ Tenzin and Karma describe themselves as "nonsectarian nuns." ${ }^{26}$ I would also describe them as "freelance nuns," since they work on a consulting basis, so to speak, leading meditation retreats, giving dharma talks when requested, and responding to calls to serve the Kuala Lumpur Buddhist community in various capacities.

An important male teacher from her preceptor's lineage would prefer that Karma, a very capable and energetic person, establish and manage a dharma center in Kuala Lumpur, but Karma has no interest in such a project. She believes many dharma centers in Malaysia to be mainly a clearinghouse for donations to the order and a comfortable temporary landing place for young Tibetan monks from India or Nepal who need international experience and practice speaking English. They also are sites for ostentatious rituals to be held on Wesak and Losar. They don't, according to Tenzin and Karma, always function as educational centers or meditation centers or serve the community in many meaningful ways. They are not sufficiently socially engaged. Thus, opting out of the safety of being backed by a powerful and well-funded male teacher, Karma works cooperatively with Tenzin to build their monastic vocations in accordance with Buddhist monastic values and practices as they understand them. While never outwardly defiant of monastic authority structures, Tenzin and Karma seem often to bypass or sidestep them, sacrificing stability and security for autonomy.

In matters of doctrine and discipline, Tenzin and Karma make up their own minds, critically assessing the Buddhist path and its discipline through engagement with teachers they meet, the textual tradition which they can access in Tibetan and English, and, most significantly, through discussion with one another. I questioned them about how they handle tricky disciplinary questions, should they arise. Whom do they consult when puzzled by a dilemma about proper conduct? In response, Karma looked at Tenzin and said: "I think I've got the best resource here. Venerable is the best vinaya teacher. We just discuss between us. We hardly get a chance to ask the teachers. We get so rushed-we never have time or opportunity to ask. We discuss issues on our own. We assess what is the benefit to others and conclude from that. We haven't come upon difficult questions that we can't decide." ${ }^{27}$ They also

\footnotetext{
24 See (Choedron 2013) for a full description of the nuns' community in Malaysia. See also (Terk 2008).

25 She made a similar statement in the Lotus Communication Network interview.

26 It is not clear to me whether Tenzin and Karma actually had in mind ris med, an important 19th century intellectual movement aimed at lessening intersectarian conflicts, when they used this term. Venerable Tenzin Dadon was originally ordained in the Gelukpa tradition, Venerable Karma Tashi Choedron in the Karma Kagyu tradition. They may have simply been referencing their cross-sectarian partnership, and eagerness to draw from all Tibetan lineages in developing their understanding and practice.

27 Interview with author, Kuala Lumpur, 11-12 July 2017.
} 
sometimes consult vinaya traditions that have been translated into English or disciplinary digests found on the Internet. Since they are ordained in the Tibetan tradition, they hold just thirty-six basic vows. Most of these, such as celibacy and not taking what is not given, are easily interpreted in the context of their lives. ${ }^{28}$

Venerables Tenzin and Karma also expressed the view that day-to-day monastic disciplinary rigor is mainly a matter of how you wear your robes, how you use your voice, how you hold your body in formal settings. In this, they follow the spirit of the classical disciplinary texts, which strongly emphasize the importance of good monastic-lay relations and performing the monastic role in a way that is pleasing and beautiful to the laity. Karma commented, "We are concerned about outward performance of vinaya to inspire confidence in the laity. Outside we are śrāvakas (non-Mahāyāna traditionalists). Inside we are tantrikas (antinomian practitioners) ... People don't see our minds. People see our bodies. So we won't say that we absolutely disregard the vinaya. That is not true. We do follow it for the sake of the laity. That is why in Frankfurt [Germany] at the end of [an international] teaching [we attended], many of the monks and nuns from the West came to say 'thank you so much for setting an example for us. We don't have much training in this part of the world because we don't have many monasteries.'"'29 Then, to provide one example of proper monastic decorum, they both drew their robes down elegantly over their left hands, demonstrating proper robe-wearing in formal situations such as official picture-taking. In discussing vinaya, Karma also made some comparisons with the male community: "It is important to [follow monastic decorum] in interacting with laity but it is also important for saigha. The nuns tend to be very careful. But the monks sometimes are very sloppy and even don't wear their robes to go to class, let their hair grow, and people aren't sure if they are sangha or not sangha and there is a lot of blurring of lines. For sangha it is not important what we show to each other, but we believe that we should not be a cause to create negative karma in others-because it is bad for laity to have negative thoughts about sangha. We should maintain behavior, otherwise we don't need to be sangha. We can just be ngakpa (unordained religious practitioners)." 30

In their hometown of Kuala Lumpur, Tenzin and Karma have built a reputation as skillful teachers. Lay Buddhist communities, which are mostly ethnically Chinese, frequently invite them to give talks and lead meditation workshops for adults and children. Theravāda temples, mostly ethnically Sri Lankan, also invite Venerables Tenzin and Karma to teach. Some of their events are large scale with one hundred or more in attendance. Others are personal and intimate. For instance, Venerable Tenzin gives dharma teachings on Tuesday mornings to a small group of especially close lay students in the apartment and often everyone shares a meal afterwards in a local vegetarian restaurant. Tenzin and Karma occasionally ride buses with groups of lay Buddhists, mostly women, on field trips to notable temples. These various relationships with laypeople are a source of financial support for Tenzin and Karma. They accept dāna (merit building material donations) from their lay supporters-in the form of direct donations or Chinese-style in auspicious red envelopes at dharma events-as well as other non-monetary forms of assistance. For instance, while I was visiting Kuala Lumpur in summer, 2017, Karma's elderly car was not running, so a series of female lay supporters, all women whose children were in school or no longer at home or who were retired, showed up every morning to cheerfully drive us around the city.

The master's degrees in Buddhist Studies Tenzin and Karma have earned are important qualifications that earn them the respect and trust of lay Buddhist communities. As Karma notes,

28 When pressed further, Karma admitted that she has been bothered by a difficult ethical question. In brief, she has yet to admit to her traditional Sikh parents, who stay just $200 \mathrm{~km}$ away in Ipoh, that she lives as a Buddhist nun. The most meaningful exchange on a matter of conduct she ever had with her preceptor, Thrangu Rinpoche, concerned the potential immorality of this omission. By Karma's reporting, the Rinpoche had responded: "You are old enough to make this decision. You should reflect on this: are you doing this to benefit sentient beings? Yes? Then it is okay that you are doing this." Interview with author, Kuala Lumpur, 11-12 July 2017.

29 Interview with author, Kuala Lumpur, 11-12 July 2017.

30 Interview with author, Kuala Lumpur, 11-12 July 2017. 
“Opportunities [to teach] arose also mainly because I completed my master's degree in Buddhist Studies. So that was very important because devotees generally want to see the qualifications of the person who is giving the dharma teaching so that the person is speaking with some conviction and some basis, some foundation." ${ }^{\prime 11}$ Karma has also remarked on several occasions, "The moment a nun gains visibility is the moment she becomes financially stable." 32 I will put this remark in context by reminding readers that many (or most) female monastics in Vajrayāna lineages are financially vulnerable, even in prosperous Malaysia.

Tenzin and Karma are often invited to attend international Buddhist conferences, especially in Asia, most recently, the Vajrayāna Conference organized by the Centre for Bhutan Studies in Thimphu, Bhutan, at which they delivered a joint paper entitled, "Feminist Presence and Expression in Vajrayāna Buddhism: Empowering and Inspiring Bhutanese Buddhist Nuns." In 2017, Venerable Karma attended the International Conference on Buddhism in the 21st Century, organized by the Union Ministry of Culture and the Nav Nalanda Mahavira University, in Rajgir, Bihar. They both attended the high-profile Belt and Road Symposium at Po Lin Monastery in Hong Kong, also in 2017. They are also regular attendees of biennial conferences for Buddhist women organized by the Buddhist women's organization, Sakyadhita, International. Their international academic presence and status as doctors of philosophy and published English-language scholars enhances their visibility as Buddhist teachers in Malaysia. In fact, I noticed while visiting them in Kuala Lumpur that many members of the Buddhist community address them as Dr. Tenzin and Dr. Karma rather than using a monastic honorific. When asked how they feel about the fact that their academic qualifications seem to have trumped their monastic status, they were unperturbed. Karma commented, "[Academic study] not only benefits our practice but we can also answer questions from people, like devotees and disciples, we can give a decent answer." In her follow up, Karma explained further that lay people find them highly approachable and ask all sorts of questions that they can't ask their male teachers, who maintain a sort of formal distance. She also ventured the opinion that sometimes traditionally trained teachers don't have the answers because they are trained only in the tradition and so they can't deal with comparative or contemporary questions. ${ }^{33}$

\section{Venerable Tenzin Dadon's Scholastic Buddhist Feminism}

Tenzin and Karma have been influenced in their intellectual life by the feminist analysis of gender and sexuality. For instance, Tenzin draws upon the work of a number of feminist scholars in her 2017 Ph.D. dissertation, "Gendered roles in Buddhist religious practices in Bhutan: A case study of two nunneries," including Judith Simmer Brown, Rita Gross, Karma Lekshe Tsomo, and Anne Klein. Her methodology is distinctly feminist, emphasizing the role of women in the religious history of Bhutan and the ways in which that history has been ignored, the systematic depravations suffered by nuns in Bhutan, and the power of religious symbolism and narrative to oppress or empower women. The question of how representation and socially inscribed gender norms actually affect women is of great interest to Tenzin, and she emphasizes the importance of ethnography as a feminist methodology that bridges the gap between androcentric textual Buddhism and the rich history of female Buddhist practice in Bhutan. ${ }^{34}$ For instance, she notes that tales of female Buddhist masters often circulate as oral traditions, but do not appear in official written histories; without further ethnographic work, such oral traditions remain invisible. Tenzin was particularly excited to discover the importance of female religious imagery in a fasting practice called nyungne. She writes:

31 Interview with Pattama Vilaileot, Lotus Communication Network. Published 2017. https: / $/$ www.youtube.com $/$ watch?v= vxQQr2ta9dI (accessed on 7 April 2018).

32 Karma made a similar statement in her Lotus Communication Network interview.

33 Interview with author, Kuala Lumpur, 11-12 July 2017.

34 See also (Sonam and Tashi Choedron forthcoming). 
This study also found some very positive symbolism/imagery which contributes to the Bhutanese nuns' confidence in their spiritual ability to become fully enlightened beings. Nuns draw inspiration from enlightened female role models such as Tāra (Tib: Drolma) and Gelongma Palmo (Skt: Bhikṣuṇi Lakṣmī), whom the nuns meditate on during the Nyungne fasting practice at Jachung Karmo in Western Bhutan. Although some of the nuns interviewed in both nunneries said that there is no difference whether there is a female image or not, most of the nuns said that the female imagery in Vajrayāna Buddhism provides inspiration for their practice and gives them hope that women also can achieve enlightenment. Some added that if there were no female images, then they would think that the dharma is only for men. As a consequence of such female Buddha symbols, most of the nuns said that females can achieve enlightenment in the female body as long as one practices sincerely because enlightenment is contingent upon the mind, which is genderless, and not on the physical body. (Sonam 2017, pp. 358-59)

In her dissertation, Tenzin argues for the potential of education to further empower Bhutanese nuns to discover gender egalitarian doctrines in Vajrayāna Buddhism. ${ }^{35}$ Her work is especially inspired by Rita Gross's Buddhist feminist classic, Buddhism After Patriarchy and Judith Simmer-Brown's Dakini's Warm Breath, in this part of her analysis.

Tenzin's use of feminist modes of analysis is particularly striking in the sections of her dissertation in which she discusses the sexual exploitation of nuns by monks and teachers in Bhutan. Discourses concerning sexual abuse within the Buddhist women's movement are often equivocal. In a conversation regarding possible panel topics for the upcoming 2019 Sakyadhita conference in Australia, one scholar, who is deeply involved with a Southeast Asian sangha in her research, warned that nuns from that community would have difficulty obtaining official permission to attend Sakyadhita conferences in the future if the tone of the conference was perceived to be overly confrontational, critical, or aggressive. She suggested that while we as academics and feminists may feel that topics such as the "male abuse of power" are available for discussion and vital to bring to light, especially at a gathering of Buddhist women, the consequences of doing so can be difficult for Buddhist monastic women functioning within traditional hierarchies. Many monastic women express only gratitude for their male teachers and are extremely reluctant to criticize them.

Karma Lekshe Tsomo, founder and former president of Sakyadhita International, connects the issue of transparency in cases of abuse to the Buddhist ethical principle of "right speech." She comments, "Buddhists try to avoid revealing others' faults. At the same time, we need systems or structures to alert people if a teacher is not reliable. For example, if an attractive young woman says she plans to do a retreat with a particular teacher who is notorious, how can we alert her to the problem without being accused of gossip or wrong speech? Of course some might say that speaking out about dangers like this is right speech" (emphasis mine. Gregory and Mrozik 2008, p. 76). While, many feminists would regard any concern for "being accused of gossip" pusillanimous, and would emphatically agree with her final comment about authentic right speech, Tsomo's ambivalence regarding the ethics of transparency within lay-monastic, student-teacher relationships has been common within contemporary Buddhist contexts. ${ }^{36}$ Notably, Tsomo and another extremely prominent Western-born nun in the Tibetan tradition, Tenzin Palmo, have both chosen to emphasize, in published statements, the culpability of women in initiating harmful sexual relations with Buddhist teachers. Both have expressed the opinion that some women are initially "flattered" by or wish to make themselves "special" by entering into relationships with powerful and charismatic male teachers (Mackenzie 1998, p. 180; Gregory and Mrozik 2008, p. 76). While certainly compatible with also

35 See also (Sonam and Juli 2016).

36 American dharma communities have begun to incorporate an ethic of transparency into their responses to sexual abuse. See (Gleig 2015). See (Miller 2018) for an example of one former "consort" attempting to negotiate the no-man's land between tantric sexual ethics and feminist sexual ethics. 
condemning the unethical behavior of transgressing dharma teachers, this indexing of women's narcissistic neediness occludes senior male teachers' greater responsibility, as well as the many thorny ethical problems related to secret sexual contact in the presence of a power differential, even if it is consensual. ${ }^{37}$

In the Tibetan Buddhist context, the special language of Tantra sometimes scripts an approach to sexual ethics that emphasizes secrecy and compliance with the teacher's wishes (Gayley 2018). The ambivalence of Buddhist monastic women on the issue of sexual abuse, even those with exposure to Western feminist traditions and a modicum of financial and institutional independence such as Karma Lekshe Tsomo and Tenzin Palmo, makes Tenzin's thorough and frank discussion of sexual abuse within Bhutanese Buddhism all the more striking. Tenzin's unapologetic analysis makes no reference to the culpability of women, the complexities of the teacher/student relationship, the importance of avoiding negative speech, or the ethical primary of secrecy. Rather she fingers the structural politics of Bhutanese monasticism, noting the nuns' institutional powerless and the neglect of their training in monastic and Vajrayāna ethics. She writes, "Had nuns been sufficiently empowered to teach their own nuns and had nuns been taught the monastic code of conduct, these incidences could have been curbed. Nuns dare not go against their teachers' wishes, paving the way for sexual exploitation by unscrupulous monks, many of whom are teachers and sometimes, even directors of nunneries" (Sonam 2017, p. 336). Tenzin's research provides anecdotal evidence of monks approaching nuns for sex, often framing their invitations within the spiritual context of Vajrayāna consort practice. She herself reports receiving several such propositions from monks in India, "citing that the practice of tantric sex would be mutually beneficial as I would be helping the monk to attain enlightenment and he, in turn, would lift me up spiritually, a prospect I found repulsive, to say the least!" (Sonam 2017, p. 341). She further describes what is likely to happen should a nun report abuse to monastic authorities. One nun who did dare to come forward and complain to a senior monastic official on behalf of another nun was promptly expelled. Apparently the official in question was himself engaged in an affair and did not want to risk exposure by investigating the case (Sonam 2017, p. 226). Remarkably, Tenzin has raised the issue of the sexual abuse of nuns with the Queen Mother of Bhutan, Ashi Tshering Yangdon Wangchuck. In response, the Queen Mother suggested, impractically, that nuns should appeal to monastic authorities and, if such appeals are ineffective, they should bring the matter to her directly. While granting the proper respect due to the Queen, Tenzin points out, somewhat crisply, how unlikely it is that: (1) abused nuns will be properly dealt with by monastic administrators; (2) they will be able to afford to travel to the capital; and (3) should they undertake such a journey, they will be admitted into the palace to meet the Queen (Sonam 2017, p. 337). The clarity of Tenzin's analysis of the structural violence within Bhutanese monasticism may well reflect her engagements with justice feminism, though she doesn't explicitly reference any theorists in those sections. ${ }^{38}$

Tenzin's willingness to openly criticize male monastic authorities in her own tradition is also undoubtedly connected to the autonomy and physical distance her life in Malaysia affords her. Financially independent and nonsectarian, Venerables Tenzin and Karma "accomplish themselves"39 daily as Buddhist nuns, not through the monolithic benediction of a male or even a female authority

37 Twenty-five years ago, the American teacher, Pema Chodron gave an interview to Tricycle magazine in which she was asked about the sexual relationships of her teacher, Chogyam Trungpa. In it, she resolutely defended his unconventional behaviors as being for the purpose of helping people, and expressed ambivalence about the notion of enforced ethical guidelines for dharma teachers. On the subject of the teacher-student relationship, she said, "As a woman I don't like that the guys are always misusing their positions and coming on to the women. But I'm tempted to say something like, when a teacher is very realized it is actually different than when they're not. But who is going to decide? Nobody can decide except the student who is in relationship with that teacher. That's an unconditional relationship. You vow to stick by each other no matter what. And that teaches something about unconditionally sticking with your own life. When things revolt you and scare you, those things point out those parts of yourself that you are rejecting" (Chodron 1993).

38 Tenzin does, however, mention the work of Kim Gutschow and Judith Simmer-Brown in the course of her analysis.

39 I borrow this existentialist language from Simone de Beauvoir, who asks, in the introduction to The Second Sex, "How, in the female condition, can a human being accomplish herself?" (de Beauvoir [1949] 2011, pp. 16-17). 
figure, but through their own varied and persistent efforts at practical and spiritual self-actualization. These include but are not limited to cultivating personal connections with authoritative teachers (without submitting wholly to their authority), the study and interpretation of texts both Buddhist and scholarly, fostering close and friendly (maitreya) relationships with lay supporters, ${ }^{40}$ and a carefully curated but ethically grounded public presence. Most of all, they "accomplish themselves" as nuns through their fruitful, affectionate, and highly intentional partnership with one another.

Tenzin and Karma often articulate a justice-oriented feminism, and draw on the canons of feminist scholarship in religion in their academic analysis of female symbolism within Vajrayāna Buddhism, but the modality of agency they display in their everyday lives most resembles the performative identity described by Judith Butler. For Butler, individuals living within socio-cultural systems are not ontologically or psychologically gendered at some point of origin and then left alone to express it out in the world. Rather, they must perform gender scripts from moment-to-moment, embodying and fulfilling norms in a layered and endlessly repeated process that creates the outward appearance of naturalness (Butler 1990, pp. 22-46). Butler argues, "Gender is always a doing ... There is no gender identity behind the expressions of gender; that identity is performatively constituted by the very 'expressions' that are said to be its result" (Butler 1990, p. 34). The reiterative, performative quality of gender is also its vulnerability. As Lois McNay describes it, "Immanent in the enactment of gender norms is the possibility that they will be performed differently, that something will go awry in the process of reiteration, and individuals will not automatically reproduce the cultural stereotypes imposed on them but will, in fact, displace them" (McNay 2015). Tenzin and Karma may not use poststructural vocabulary to describe their own iterative modes of gendered monastic identity, but they understand how to get on with it well enough. While they strive to embody female Buddhist monastic norms properly, drawing down their robes to elegantly cover their left hands, so to speak, they do so with a high degree of critical reflection, performing those norms a bit "differently" at times, strategically allowing things to go slightly "awry," and subtly "displacing" stereotypical expectations for nuns.

While Tenzin and Karma explicitly engage liberal feminists such as Rita Gross, and while the particular mode of agency they display in occupying gendered monastic roles can be described by the poststructural feminist theories of, for instance, Judith Butler, it is important to note that feminist discourses are not internal to Buddhist doctrine, practice, ethics, or institutional structures, the primary source of meaning and self-understanding for Tenzin and Karma. Just as Salgado's dasasilmātās may understand their own gender-related struggles primarily in terms of the Buddhist conception of suffering, Tenzin and Karma strive to fulfill Buddhist ethical ideals and to reach soteriological goals they understand primarily in terms of Buddhist wisdom, no matter their professed and explicit feminism. Just as the self-understandings and thought processes of pious Muslim women in Egypt are not, in Saba Mahmood's words, encompassed by terms that "belong to ... a feminist discourse" such as "obedience versus rebellion, compliance versus resistance, or submission versus subversion" (Mahmood 2005, p. 180), the motivations and ethical self-understanding of Tenzin and Karma are not adequately captured by feminist ideas like "equality," "autonomy," and "women's liberation." They should not, as Mahmood puts it, be "subsumed within a teleological process of improvement" to be defined in terms of the "liberal project" (Mahmood 2005, p. 198). Furthermore, it behooves feminists to allow their own conceptual categories and liberatory practices to be challenged by parafeminist and feminist Buddhist discourses promulgated by agentive Buddhist women such as Tenzin and Karma. The modes of agency Tenzin and Karma deploy (which include creative engagement with Buddhist ethical and legal norms), and their calm (śamatha) and "friendly" (maitreya) affective style in building coalitions across difference, are particularly illuminating, and will be examined more closely after the second case study is introduced.

40 While it is not the focus of my discussion here, the close relationship that Tenzin and Karma enjoy with their circle of lay supporters resembles the affection and respect Sri Lankan lay people profess for their nuns, the significance of which has been noted by Mrozik (2014). 


\section{Innovative Female Buddhist Monasticisms: Nepal}

Like Malaysia, Nepal is home to several varieties of Buddhism, including Newar Buddhism with its unique noncelibate form of monasticism and elaborate ritualism, the Vajrayāna Buddhism practiced by culturally Tibetan communities (those who have lived inside of Nepal's borders for generations and those who are more recent immigrants from Tibet), and Theravāda Buddhism, which was established in Nepal during the course of the twentieth century (Bechert and Hartmann 1988; Levine and Gellner 2005). The lineage of Theravāda bhikșunīs (fully ordained nuns) in Nepal was officially revived in 1988 when three Nepali anagārikās (literally, "homeless women"; members of alternative female Buddhist renunciant orders) received bhikșuñ ordination with the help of Fo Guang Shan nuns in Los Angeles. Among these was Bhikkhuni Dhammawati, ${ }^{41}$ head of Dharmakīrti Vihāra in Kathmandu, founder of Gautamī Vihāra in Lumbini, and an important figure in female Buddhist monasticism in Nepal. As of 2011 there were twenty-nine Theravāda bhikṣunīs, and over one hundred celibate, ten-precept anagārikās in Nepal (Dhammananda 2011; Nyanawati 2008). Female Theravāda communities in Nepal are influenced by Burmese traditions of alternative female renunciation, and have been instrumental in introducing Burmese styles of vipassana meditation to lay Buddhists. Sarah Levine and David Gellner connect younger Nepali women's interest in the Theravāda orders to the social environments they face, however, not to any rising interest in meditation: "For women, ordination is more of an act of emancipation than of 'renunciation' ... Undoubtedly some adult female recruits 'go into homelessness' in order to have more time to meditate and study buddha dharma, but all are motivated by the urgent desire to escape marriage and motherhood, which, despite the fact the women are now entering the professions in considerable numbers, is still widely regarded as the only entirely acceptable adult female role" (Levine and Gellner 2005, p. 273).

Peace Grove Institute, the second of the two case studies offered in this essay, is a small community of twenty-six girls between the ages of seven and twenty-something from areas around Lumbini. Lumbini is an important Buddhist pilgrimage town in the Terai region of Nepal, the site of the temple (inscribed in UNESCO's list of World Heritage sites in 1997) marking what is believed to be the birthplace of Śākyamuni Buddha. Lumbini town also boasts many international temples in an area set aside by the Nepali government to be developed for Buddhist education, pilgrimage, and tourism. Over 1.5 million tourists visited Lumbini from Nepal, India, Buddhist Asia, and the West in 2017, according to The Kathmandu Post (Amrol 2018). This figure is expected to increase significantly after the completion of an international airport in nearby Bhairahawa. Despite its importance as a pilgrimage area, the district in which the town of Lumbini is located, Rupandehi, is relatively poor. It is mainly an agricultural area whose residents are Hindu, and Muslim, not primarily Buddhist, ${ }^{42}$ and who have limited access to health care, education, and basic infrastructure. Due to local gender norms, health care and education are generally less available to women and girls than they are to men and boys in Lumbini. ${ }^{43}$

Peace Grove Institute is headed by a locally born, socially engaged, Theravāda monk called Metteyya Sakyaputta. Venerable Metteyya was born into a local Brahmin, not Buddhist, family. He began studying

41 I spell Bhikkhuni Dhammawati's name using the Pāli rather than the Sanskrit term for nun, and without diacritics. This is the way her name most frequently appears in publications and online. Interestingly, the Buddhist terminology used in Nepali Theravāda communities appears to vacillate between Pāli and Sanskrit, reflecting their hybrid heritage.

42 See Letizia (2014) for an analysis of Buddhist identity and Buddhist activism in the area.

43 The LSSF website makes the following statement regarding the status of women and girls in Lumbini: "In the Lumbini area, girls are considered a liability from the time they are born. Sons continue the blood lineage; daughters do not. Sons look after their parents in their old age and perform religious rituals; daughters are lost to another family through marriage. Thus people consider daughters to be someone else's property; to be reared and given in matrimony as soon as possible. Parents have to pay dowries so high, that families can be indebted for decades. The younger the girl is, the lower the dowry, and the shorter the amount of time required to provide care for the child. As a result, especially in poor families, education is seen as a wasted investment and girls usually receive less nutrition and medical care than their brothers. It is no surprise then that more girls than boys die before they are 5 years old. In Nepal, where one child in every 15 is malnourished, the figure is two times higher for girls." http://servelumbini.org/karuna-girls-college/ (accessed on 7 April 2018). 
Buddhism at the age of nine with his root teacher, Venerable Anagarika Sujata, and was subsequently ordained by Mahathero Venerable Bhikkhu Maitri. Both of Venerable Metteyya's teachers have been active in establishing Theravāda Buddhism in Lumbini. ${ }^{44}$ Deeply engaged in the economic and social issues faced by his community, Metteyya is founder of the Lumbini Social Service Foundation, a Lumbini based NGO, and has built several schools, one of which is an all-girls high school, Karuna Girls College, the only one in the area. ${ }^{45}$ Although still only in his late twenties, he also currently serves as the Vice Chairman of the Lumbini Development Trust, the government organization that oversees the central pilgrimage area, known as the Master Plan.

Before his ordination, when he was just fifteen-years-old, Metteyya began an academic camp to provide tutoring for local teens. They met under a mango tree. This same tree now grows at the center of the Metta School, built on donated land with funds raised by Metteyya and his team. The Metta School serves 685 students and employs eighteen teachers to teach kindergarten through eighth grade. Since those early days, Metteyya has also established a village school at Punnihawa and the Karuna Girls College, with the help of the Canadian nun and founder of the Canadian Engaged Buddhism Association, Guruma Bodhi Sakyadhita. Karuna Girls College is a "Centre for Women's Liberation" providing grade six through twelve level education. In addition to academics, the Karuna school teaches hygiene and health, physical education, environmental perspectives, and offers classes on journalism, art, and music. The Karuna Girls College is also a center for vocational and dharma instruction for local women, many of whom are the mothers, grandmothers, older sisters, and aunts of Karuna students. The page for the Karuna Girls College on the LSSF website proclaims, hopefully, "We believe that educated and empowered girls can help change the future of their society." ${ }^{46}$ The high-school-aged girls from Peace Grove attend Karuna school.

By his own account, Metteyya was inspired to begin the Peace Grove Institute, a Buddhist monastic residential facility for girls, after learning about certain interventions by Bhikkhuni Dhammawati. ${ }^{47}$ Beginning in the late 1960's, Dhammawati began to offer her own Kathmandu center, Dharmakīrti Vihāra, as a retreat facility for Newar Buddhist girls of an age to undergo bārh $\bar{a}$, a coming-of-age observance that prepares them ritually for the advent of menses and sexual maturity. ${ }^{48}$ Rather than banishing them to dark rooms to undergo a period of ritual liminality in preparation for the transition into social adulthood, Dhammawati suggested that ritually observant Newar families send their $b \bar{a} r h \bar{a}$ girls to Dharmakīrti Vihāra for the required period of separation. Dhammawati called the retreat girls rssinins (the feminine of the term $r s ̦ i$, a Sanskrit word for seer or religious adept) and fashioned a ritual of temporary ordination (which she named $r \sin \bar{\imath}$ pabbajj $\bar{a}^{49}$ ) in which the girls kept eight precepts, followed the nunnery schedule, and wore robes of a distinctive dark red color. ${ }^{50}$ She used the opportunity to educate the girls about Theravāda Buddhism, a tradition quite distinct from the Newar Buddhist traditions of their community (Bechert and Hartmann 1988, p. 26; Levine and Gellner 2005, p. 91).

In founding Peace Grove Institute, Metteyya also responded to a ritualized and vulnerable moment for girls living in the villages around Lumbini: marriage. Once engaged-to-be-married, young

44 http:/ / www.lumbininuns.org/index.php/teachers.html (accessed on 1 June 2018).

45 http://servelumbini.org/ (accessed on 7 April 2018).

46 http:/ / servelumbini.org/karuna-girls-college/ (accessed on 7 April 2018).

47 For Dhammawati's biography and importance, see (Levine 2016 and Levine and Gellner 2005). Bhikkhuni Dhammawati attended the 1987 and 2000 Sakyadhita conferences in Bodh Gaya, India and Lumbini, Nepal respectively. According to both Levine and Gellner, and Koppedrayer and Fenn, attending Sakyadhita gatherings influenced her position on nuns' status and training. Koppedrayer and Fenn (2008) note, "Prior to attending a Sakyadhita conference she did not believe in the full ordination of women nor did she value secular education for her nuns. She changed her mind on both issues and with the contacts she made at the conference she was able to make arrangements to have some nuns study abroad" (p. 62). Levine and Gellner (2005) describe the influence of the 1987 Bodh Gaya gathering at some length (pp. 180-86). It is worth noting the Dhammawati was ordained as a bhiksunī one year later (1988) in Los Angeles.

48 Allen (1996, pp. 100-32) and (Emmrich 2014) provide ethnographic insight into this Newar ritual.

49 Bhikkhuni Dhammawati seems to have drawn from both the Sanskrit and Pāli languages in coining this term.

50 According to Levine and Gellner (2005), other Theravāda nunneries in the Kathmandu Valley have taken up the practice of rṣinī pabbajjā (p. 91). 
village girls are sometimes kept home from school, even if the wedding and subsequent transfer to their in-laws' home is not to take place for several years. This can be at the request of future in-laws concerned about their new brides' purity and virtue. In particular, Metteyya and Guruma Bodhi Sakyadhita, whom Metteyya refers to as his dharma mother, became concerned that certain academically talented and promising girls attending his schools were not able to finish their education once betrothed. These were girls who, if educated, could make a difference in their community. The nunnery solves this problem for a few fortunate local girls (and it has a long wait list) by providing a semi-monastic, socially safe space under the protection of which the girls can continue to pursue education. Because they respect both Metteyya and the practices of Buddhist asceticism, most local parents and elders would hesitate to accuse Metteyya's nuns of impropriety or lack of feminine virtue, no matter that they mix with boys or young male teachers at school, no matter that they are personally ambitious.

The girls in residence at Peace Grove Institute occupy a ritual status that is in between lay life and higher ordination as a bhikhunī or nun. They do not hold as many vows as, say Karma and Tenzin. This graduated system of discipline is orthodox in Buddhist monasticism. There is textual precedent for very young monastics to hold only a portion of even the ten novice vows in the classical tradition (Langenberg 2012). Metteyya, like Dhammawati, calls the girls "rṣinīs." All the girls wear the distinctive dark red color that Dhammawati's charges also wear during ṛsinī pabbajjā. Instead of the requisite three monastic robes, however, they are sometimes seen wearing the salwar kamiz tunic and loose pants style that girls often wear in India and Nepal since it is easier for moving around freely, playing games, riding bikes, or cooking. Importantly, the girls also don't shave their heads. Metteyya told me that he made a special application to the Theravāda sangha council in Kathmandu regarding the cutting of their hair. Ordinarily, the hair is the first thing to go to mark the ritual change of status from lay to monastic. But cutting the girls' hair turned out to be a serious obstacle to securing the parents' permission. In rural South Asia, long hair is a primary gender marker for girls and a factor in whether or not they are judged beautiful.

The rșiniss of Peace Grove may not necessarily hold their vows permanently or go on to become fully ordained bhikkhuniss, but some of them may decide to do so. Of the oldest girls, four have received nurse-midwife training. Another is studying for a graduate degree in Buddhist Studies at a local Buddhist University. The teenagers, who attend Karuna Girls College, have great plans for themselves. Some are budding journalists, others love science, yet others have learned to play instruments. The younger ones attend the Metta School, and carry on its school tradition, initiated in the early days by Metteyya himself, of accomplishing much with limited material resources but abundant hope. The smallest resident of Peace Grove Institute was abandoned by her parents during the time of the earthquake in April of 2015 and has yet to undergo initiation of any type.

Most of them still in grammar school or high school, the Peace Grove nuns are not versed in the canons of feminist Buddhist scholarship as are Tenzin and Karma. Still, the language of "female empowerment" features prominently on the LSSF website, an implicitly feminist goal. Moreover, Karuna Girls College and the Peace Grove Institute, which are physically adjacent, create a space of female learning and aspiration that is quite distinct from other social spaces in Lumbini. Venerable Metteyya, who may not himself be widely read in feminist thought, sometimes "experiments" with disrupting the gender-hierarchical assumptions of his students. For instance, while hosting a group of American college students ${ }^{51}$ at the Bodhi Institute, a center for Buddhist study and also the living space of the community of young male novice monks he oversees, Metteyya placed one of the older rșinīs in charge of managing the meals and other arrangements for the American visitors. In other words, Metteyya placed a young woman in charge of an important and exciting event taking place

51 This group, students from Eckerd College, a liberal arts college in St. Petersburg, Florida, visited Lumbini in January 2018 as part of a study abroad course. I was the faculty leader on that course. 
in a socially male space. As part of her managerial work, the young nun was often in the position of issuing orders to the young monks living and working at the Bodhi Institute. Metteyya expressed to me his interest in observing the adjustments of behavior and attitude that accompanied this sanctioned inversion of customary structures of authority.

The Buddhist lives of Tenzin and Karma intersect with but are not adequately captured by various feminist discourses. The lives of the Peace Grove nuns are, in some ways, more accessible to a liberal feminist discourse that emphasizes autonomy, resistance, and equality, but, in others, far less so. Unlike Tenzin and Karma, the girls and young women who live together at Peace Grove occupy a social and institutional environment structured by hierarchies of age, ritual status, and, to a somewhat lesser extent given their female-focused living environment, gender. Their performance of obedience in this hierarchical environment is graceful and, it would appear, willing. While they live unusual, even radical female lives for Lumbini, they have, in effect, exchanged the gender and age hierarchies of their birth homes for monastic hierarchies. This exchange is partial because they still are subject to the wishes of their parents, and, despite their monastic status, their lives still richly imbricate the lives of lay peers and other members of the community, a large and diverse selection of whom they meet at school every day. While some of their goals-education, control over their own female bodies, delaying marriage or avoiding it all together-seem to fall comfortably within the bounds of what Mahmood calls "the liberal project," their methods and style of gender performance are distinct to their Nepali Buddhist ritual and institutional context. Freedom and agency for the Peace Grove nuns does not manifest as defiance of traditional norms or critique of patriarchal authority. Rather, outwardly at least, the Peace Grove nuns are chaste, obedient, norm followers.

\section{The Female Agency of Monastic "Textual Communities"}

Although one might be inclined to associate the agency demonstrated by Bhikkhuni Dhammawati, Metteyya Sakyaputta, Guruma Bodhi Sakyadhita, Tenzin Dadon, and Karma Tashi Choedron in adapting the practices and institutional structures ordained in vinaya with Buddhist modernity, evidence suggests that an uncritical and strict obedience to the letter of monastic law, a vinaya fundamentalism if you will, has never been usual in Buddhist monasticism. Influenced by Steven Collins's views on canonicity in the Theravāda tradition, ${ }^{52}$ Anne Blackburn argues that the canonical status of vinaya texts does not guarantee they were rigidly followed in monastic communities. According to Blackburn, the formal disciplinary canon (vinaya-pitaka) is symbolically important but has not, in many cases, actually been read or used for day-to-day discipline, at least not fully and literally. For instance, medieval communities in Sri Lanka seeking to train monastics and clarify disciplinary questions employed a "practical canon" consisting in certain ethically relevant sutta texts and a vinaya digest (Blackburn 1999). Working on higher ordination in contemporary nuns' communities, Ute Hüsken and Petra Kieffer-Pülz argue that it is inevitable vinaya rules will be interpreted and adapted by particular communities at particular times and places. They note, "although rules are the foundational framework, they can never cover all contextual issues, unless they are adapted when and as the need arises" (Hüsken and Kieffer-Pülz 2012, p. 266). ${ }^{53}$

52 In examining the formation and significance of the Pāli canon, Steven Collins concludes, "the actual importance of what we know as the Pāli Canon has not lain in the specific texts collected in that list, but rather in the idea of such a collection" (Collins 1990, p. 104).

53 Scholars analyzing the proceedings of the 2007 Hamburg conference on reestablishing the bhikṣuni order in the Tibetan sangha, for instance, have noted that, while bhikșunis from Europe, North America, and Australia, and the academic scholars of the vinaya invited by the organizers, tended to regard the issue of higher ordination for women as a legal puzzle, a group of Himalayan nuns in attendance apparently held the view that ordination is a culturally rooted and ritually transformative event (Hüsken and Kieffer-Pülz 2012; Mrozik 2009). The Himalayan nuns, who had not been granted a place in the program and spoke from the floor, insisted upon the importance of being ordained according to their own Mūlasarvāstivāda traditions as orally transmitted through their teachers, and in their own Tibetan language (Mrozik 2009, p. 370). 
As Hūsken and Kieffer-Pülz argue, the notion of "practical canon," developed mainly within the context of historical studies, is relevant to understanding contemporary communities. Similar adaptations and interpretations are evident in engagements with Buddhist monastic hierarchies and legal traditions by Venerables Tenzin, Karma, and Metteyya. For instance, despite the fact that classical Buddhist law places the female community under the direct supervision of the male community, Tenzin and Karma prefer to ally with one another and keep a rather cagey distance from powerful male monastic leaders, even when those leaders offer to support them. They do this while expressing gratitude and appreciation for those same leaders. In fact, Blackburn's notion of "practical canon" applies exceedingly well to Tenzin and Karma's understanding of vinaya, as they themselves articulate it. While academic by inclination and training and highly engaged with the broader concept of Buddhist discipline and training as well as its day-to-day practice in the complex social and political environment of contemporary urban Malaysia, they do not typically turn to the canonical vinaya, Mūlasarvāstivāda or otherwise, when seeking to answers questions of discipline. When queried directly, Tenzin and Karma defined the concept of vinaya improvisationally, resourcing the basic ethical principles of the Buddhist path: 'The vinaya in Tibetan means dulwa which means 'tamed,' taming the mind, so we don't need to worry much about robes and small small details. Some other people are very crooked inside though they look very neat outside. Others are running around but have a tamed mind. That's why we don't have very strict rules about money, etc. ${ }^{\prime 54}$ At the same time, Tenzin and Karma strongly emphasized the importance of formal monastic decorum, of a pleasing and dignified presentation in order to inspire the confidence of their lay supporters (for whom doubting their virtue or disciplinary rigor would result in demerit). In matters of decorum, Tenzin, whose long training in monastic life has resulted in a deep embodied knowledge of beautiful monastic performance, operates as guide and rulebook. When questioned further about what written sources they consult on vinaya questions, should they feel the need, they particularly mentioned an online digest of thirty-six śrāmaner $\bar{\imath}$ precepts posted by Bhikshuni Thubten Chodron, saying they reference these "when in doubt about the precepts." 55

Together with his dharma mother, Guruma Bodhi Sakyadhita, and in consultation with his teachers, Metteyya has crafted a style of monasticism artfully designed to be of maximum benefit to his community. The form of monastic virtue Metteyya teaches is an excellent option for the girls. In addition to its moral and spiritual benefits, it provides social cover under the protection of which girls can continue their educations without being criticized, ostracized by their communities, or alienated from their families. Although it is not a reflection of the Peace Grove nuns' religious sincerity, the classical Buddhist ideal of permanent renunciation and ordained life lived at the highest possible level of discipline is not strongly emphasized at Peace Grove. Aiming for a novice or even sub-novice level of monastic discipline and no higher (except in select cases) is ideal for Metteyya's purposes. It enables the girls to wear monastic colors but to forego the headshaving, to eat at night, to ride bikes, even while benefiting from representational traditions of the "good Buddhist nun." Furthermore, what I call the "semi-monastic" environment of Peace Grove means that the families involved are insured of their celibate daughters' virtue but need not relinquish marriage as a future possibility. This situation creates a space of permission, cooperation, and mutual respect with families that makes it possible for them to willingly entrust their daughters to Metteyya.

The Malaysian and Nepalese examples given here are both situations in which female and pro-female monastics engage the performative, didactic, and legal dimensions of Buddhist monasticism in a dialogical and intentional manner, but in close consultation with local community needs, norms, and sensitivities. This communal critical engagement with authoritative texts resembles another of Ann Blackburn's important theoretical interventions: her concept of "textual community,"

54 Karma. Interview with author, Kuala Lumpur, 11-12 July 2017.

55 http://thubtenchodron.org/1996/06/precepts/. 
defined as "those who participate in shared practices of reading, writing, listening, interpretation, and performance, with reference to the same body of texts (perhaps, but not necessarily, a formal curriculum)." According to Blackburn, thinking in terms of "textual community" corrects two major methodological mistakes in Buddhist Studies: (1) textual reductionism-that is, assuming that a religion or a religious community is properly defined by an essence which is to be located in its major text or texts; and (2) "critical post-textualism" or rejecting texts completely in favor of practice (Blackburn 2012, p. 164). The notion of Buddhist "textual communities" also supplies a corrective of and enhancement to older feminist theories of representation and social norming in religion that exaggerate the oppressive effect of patriarchal symbol systems and narrative traditions on social behavior. Certainly, representational, didactic, and disciplinary religious texts influence gender behaviors in communities, but, as the ethnographic examples adduced here demonstrate, they can be and generally are engaged dialogically and critically as part of a socially grounded shared interpretive act. In other words, religious communities, especially those occupied by women and girls, are not the passive recipients of negative gender representations and hierarchical social norming found in religious texts. Rather, they actively interpret and adapt religious discourses.

\section{Imperfect Alliances}

In her introduction to a reader in feminism and religion, Elizabeth Castelli, gives a succinct account of the difficult relationship liberal feminism has had with "religion":

It has been an obstacle to some conversations that many feminists, whether activists or academics, have tended to read "religion" as an abstraction solely in negative terms-reading "religion" only as a form of constraint both ideologically and institutionally, and reading the embrace of religious affiliations or allegiances primarily as a sign of false consciousness. This negative rendering of "religion" is in many respects an ironic holdover from feminism's own Enlightenment inheritance. (Castelli 2001, p. 5)

As the richness of the many essays reprinted in Castelli's reader indicates, feminist scholars of religion have moved well beyond a simplistic condemnation of religion as a tool of the patriarchy, and, in the process, have broadened the scope of feminism. While female Buddhist monastics engage feminist discourse and have sometimes created their own Buddhist feminisms, their lived and spoken approaches to gender, sexuality, and progressive social change can also push at or rupture the feminist discursive envelope in instructive ways. Furthermore, in some monastic dispositions, "victim blaming" in cases of sexual abuse, may fall well outside of the political and ethical framework of feminism.

Female and pro-female Buddhist monastics are particularly instructive interlocutors in the areas of coalition building and working across difference. Their skillfulness is supported, perhaps, by ideas about human sociality and embodied existence that are deeply embedded in Buddhist doctrinal formulations. Naive or romantic interpreters of Buddhist ethical philosophy sometimes understand the Buddhist doctrine of interdependence as being about harmony, connection, and oneness. ${ }^{56}$ In fact, in the classical Buddhist view, interdependence is the very origin point of human suffering. It is an ontological situation of tragic dependence that inevitably leads to great pain, vulnerability and violence. Confronting our radical interdependence is also, however, the starting place of liberation. As in existence, so in politics. The socially engaged Buddhist monastics introduced here are masters of coalition building, virtuosos of imperfect alliances, honest philosophers of interdependence. They

56 See (McMahan 2008, pp. 162-65). In a 2002 Tricycle article, Thanissaro Bhikkhu also traces the roots of this modern misreading to nineteenth-century Romanticism: "Many Americans, when new to Buddhism, are struck by the uncanny familiarity of what seem to be its central concepts: interconnectedness, wholeness, ego-transcendence. But what they may not realize is that the concepts sound familiar because they are familiar. To a large extent, they come not from the Buddha's teachings but from the dharma gate of Western psychology, through which the Buddha's words have been filtered. They draw less from the root sources of the dharma than from their own hidden roots in Western culture-the thought of the German Romantics." 
are not surprised that the "desire realm" in which we live out our human lives, according to classical Buddhist cosmology, is a place of violence, craving, and interpersonal suffering. They are prepared to work to mitigate such social realities. Furthermore, their embrace of the Buddhist ethic of maitrī/metta (friendliness) and commitment to mental, verbal, and physical self-discipline colors the outward tone of their interactions with others. It also bolsters, one suspects, their inner capacity for weathering conflict without reacting violently.

Venerables Tenzin and Karma exist at the juncture of many political fault lines. They are independent and female in a religious environment that rewards membership and maleness. They are freelance in a system based on institutional sponsorship. They are monastic in an academic environment that prefers secularity. They are Buddhist in a Muslim country. They are Bhutanese and Indian, following a Tibetan tradition, in a Buddhist cultural environment that is mostly Chinese. Their public response to this often difficult, ultra-intersectional, positionality is almost unfailingly dignified, nonviolent, open, polite, and generous. While privately they may feel stressed, aggrieved, and sometimes angry, publicly they prioritize partnership and cooperation over any forceful assertion of identity.

Venerable Metteyya is also a master of coalition building. While highly critical of the limitations placed on women in his community, appalled by incidents of gender-based violence, articulate about the positive consequences of allowing women to become educated leaders, he does not propose a radical overturning of the social order. Rather he works inside the existing structures, softening them from within. For instance, he knows that securing the participation of the village mothers and grandmothers, some of whom are the fiercest defenders of gender norms and most of whom are not Buddhist, is essential. Every month, he holds full moon feasts at the nunnery and includes the community. This skillful use of the ritual calendar also has the subtle effect of harnessing the sense of auspicious portent, communal celebration, and purification that South Asian Buddhist and Hindu communities may already associate with the full moon. The mothers and grandmothers come to cook and socialize. The fathers and uncles come to eat. The ones he hopes to persuade that the education of girls is important and worthwhile are invited in, literally, not alienated or excluded or criticized. More importantly, Metteyya's creative and intentional deployment of monastic discipline in the service of female empowerment and social improvement has the effect of creating modest, not overtly bold or sassy, girls, as per local cultural expectations. His young nuns, however, display a distinctly "parafeminist" modality of modesty, one that also accommodates a high level of education and, indeed, agency.

The tactful, one could say mindful, tone of these Buddhist interventions, especially their non-reliance on a fully shared identity as a basis for collective action and community building, resembles dynamics of coalition building across difference that Judith Butler has addressed in her latest book, Notes Towards a Performative Theory of Assembly. There, Butler quotes the African American feminist and civil rights activist, Bernice Johnson Reagon who, in describing her work in building political coalitions once commented, "I feel as if I'm gonna keel over any minute and die. That is often what it feels like if you're really doing coalition work. Most of the time you feel threatened to the core and if you don't, you're not really doing no coalescing. You don't go into coalition because you like it" (Butler 2015, p. 151). ${ }^{57}$ Butler admires Reagon's truth telling because liberal progressives, including feminists, can be political narcissists, condemning as ethically egregious or politically odious all but their perfect allies. As Butler said in an interview she gave after Towards a Performative Theory of Assembly was published, "What worries me is that many of us form our sense of obligation toward another on the basis of feelings of identification. If someone else is like us, and that likeness is readily recognizable, then we are more inclined to respond in the way that we would have others respond

57 Butler doesn't cite a source for this quotation, but I found it at (Reagon 1983, p. 356). Either Butler leaves out some intervening material in the middle of the quote, or Reagon said something very similar in a different place. 
to us. The harder task is to maintain an obligation to those by whom we feel ourselves to have been injured, to those we fear, or to those whose difference from us seems to be quite severe" (Butler and Berbec 2017). In fact, she argues, we cannot be free except in a sphere of freedom that we build with other people, some of whom may be, as she puts it, "unchosen."

Ann Blackburn's notion of "textual communities" that embrace modalities of agency based at least in part on obedience to community-based norms also relates in important ways to the question of coalition building within and across communities. Building up strategies of change that, while respectful to religious authority and in sensitive relationship to community, are also in some sense progressive, requires skill in negotiating with the "unchosen." Reaching across to other communities with significantly different habits of gender norming, or to conservative members of one's own community, necessitates a capacity for forming alliances with imperfect partners, even those with whom one may fundamentally disagree.

\section{Conclusions}

Female and pro-female monastics occupy a hierarchical, norm-driven, non-secular space that, to the unreformed liberal secular feminist eye, may appear unliberatory. As Butler and other poststructural or postcolonial feminists have frequently argued, however, liberal feminism is itself rife with self-contradiction. Its identity politics reifies the very gender concepts it seeks to undermine in the interest of gender parity. Its resistance to gender norms, especially those found within religion, is often predicated on what amounts to an ontological, quasi-spiritual belief in an unfettered transcendent self. It has sometimes failed to interrogate power differentials based on class, race, or nationality even while exposing the insidious structures that enforce gender hierarchies and perpetuate gender violence. This essay argues for a continued expansion of the feminist frame to accommodate the illuminating perspectives of religious people, in this case female and pro-female monastics. It is not unusual for contemporary Buddhist monastics to train a critical eye on the gendered representations and institutions of their own tradition while, at the same time, locating power and agency in the sincere and profound fulfillment of its ethical norms and respect for its structures of authority. Female monastics (and their male advocates) are particularly interesting as agents of social change even in the face of profound differences in outlook, entrenched conservatism, and gender-based violence. Like Bernice Johnson Reagon, and their own progenitor, Mahapajāpatī Gautamī, female and pro-female Buddhist monastics model critical and principled coalition building with imperfect allies, even when, or especially when, "threatened to the core."

Conflicts of Interest: The author declares no conflict of interest.

\section{References}

Abu-Lughod, Lila. 1990. The Romance of Resistance: Tracing Transformations of Power through Bedouin Women. American Ethnologist 17: 41-55. [CrossRef]

Agarwal, Bina. 1994. Positioning the Western Feminist Agenda: A Comment. Indian Journal of Gender Studies 12: 249-55. [CrossRef]

Allen, Michael. 1996. The Cult of Kumari. Virgin Worship in Nepal. Kathmandu: Mandala Book Point.

Amrol, Amrita. 2018. Lumbini saw more than $1.55 \mathrm{~m}$ tourists in 2017. The Kathmandu Post, January 13. Available online: http:/ / kathmandupost.ekantipur.com/news/2018-01-13/lumbini-saw-more-than-155m-touristsin-2017.html (accessed on 2 June 2018).

Anālayo, Bhikkhu. 2008. Theories on the Foundation of the Nuns' Order-A Critical Evaluation. Journal of the Center for Buddhist Studies, Sri Lanka 6: 105-42.

Atkins, Paul S. 2008. Chigo in the Medieval Japanese Imagination. The Journal of Asian Studies 67: 947-70. [CrossRef]

Bartholomeusz, Tessa. 1994. Women under the Bō Tree: Buddhist Nuns in Sri Lanka. Cambridge: Cambridge University Press.

Bechert, Heinz, and Jens-Uwe Hartmann. 1988. Observations on the Reform of Buddhism in Nepal. Journal of the Nepal Research Center 8: 1-30. 
Blackburn, Anne M. 1999. Looking for the Vinaya: Monastic Discipline in the Practical Canons of the Theravāda. Journal of the International Association of Buddhist Studies 22: 281-310.

Blackburn, Anne M. 2012. The text and the world. In The Cambridge Companion to Religious Studies. Edited by Robert A. Orsi. Cambridge: Cambridge University Press, pp. 151-76.

Butler, Judith. 1990. Gender Trouble. New York: Routledge.

Butler, Judith. 2015. Notes toward a Performative Theory of Assembly. Cambridge: Harvard University Press.

Butler, Judith, and Stephanie Berbec. 2017. We Are Worldless without One Another: An Interview with Judity Butler. The Other Journal: An Intersection of Theology and Culture. Available online: https: / / theotherjournal.com/2017/06/26/worldless-without-one-another-interview-judith-butler/ (accessed on 7 April 2018).

Cabezón, José Ignacio. 1993. Homosexuality and Buddhism. In Homosexuality and World Religions. Edited by Arlene Swidler. Valley Forge: Trinity Press International, pp. 81-101.

Cabezón, José Ignacio. 2017. Sexuality in Classical South Asian Buddhism. Somerville: Wisdom Publications.

Castelli, Elizabeth A. 2001. Women, Gender, Religion: Troubling Categories and Transforming Knowledge. In Women, Gender, Religion: A Reader. Edited by Elizabeth A. Castelli. New York: Palgrave, pp. 3-25.

Choden, Sonam. 2017. Himalayan Feminism. Paper presented at the 15th Sakyadhita International Conference on Buddhist Women, Hong Kong, China, June 22-28.

Chodron, Pema. 1993. No Right, No Wrong: An Interview with Pema Chödrön. Tricycle 3: 16-24.

Choedron, Karma Tashi. 2013. Buddha's Lone Rangers: Vajrayana Buddhist Nuns of Contemporary Suvarnabhumi. Paper presented at the 13th Sakyadhita International Conference on Buddhist Women, Vaishali, India, January 5-12.

Collins, Steven. 1990. On the Very Idea of the Pali Canon. Journal of the Pali Text Society 15: 89-126.

de Beauvoir, Simone. 2011. The Second Sex. Translated by Constance Borde, and Sheila Malovany-Chevallier. New York: Vintage Books. First published 1949.

Dechen, Lobsang. 2010. Buddhist Women's Role in the Sangha. In Dignity and Discipline: Reviving Full Ordination for Buddhist Nuns. Edited by Thea Mohr and Jampa Tsedroen. Boston: Wisdom Publications, pp. 207-10.

DeVido, Elise. 2010. Taiwan's Buddhist Nuns. Albany: SUNY Press.

Dhammananda, Bhikkhunī. 2011. Establishing the Bhikkhunī Sangha in Nepal. Paper presented at the 12th Sakyadhita International Conference on Buddhist Women, Bangkok, Thailand, June 12-18.

Emmrich, Christoph. 2014. Ritual Period: A Comparative Study of Three Newar Buddhist Menarch Manuals. South Asia: Journal of South Asian Studies 37: 80-103. [CrossRef]

Falk, Monica Lindberg. 2007. Making Fields of Merit: Buddhist Female Ascetics and Gendered Orders in Thailand. Seattle: University of Washington Press.

Faure, Bernard. 1998. The Red Thread: Buddhist Approaches to Sexuality. Princeton: Princeton University Press.

Gayley, Holly. 2018. Revisiting the 'Secret Consort' (gsang yum) in Tibetan Buddhism. Religions 9: 179. [CrossRef]

Gleig, Ann. 2012. Queering Buddhism or Buddhist De-Queering? Reflecting on Differences amongst Western LGBTQI Buddhists and the Limits of Liberal Convert Buddhism. Theology E Sexuality 18: 198-214.

Gleig, Ann. 2015. The Shadow of the Roshi: Sex, Scandal, and Secrecy in American Zen Buddhism. Sweeping Zen. Available online: http:/ / sweepingzen.com/the-shadow-of-the-roshi-sex-scandal-and-secrecy-in-americanzen-buddhism/ (accessed on June 12018 ).

Gregory, Peter N., and Susanne Mrozik, eds. 2008. Women Practicing Buddhism: American Experiences. Boston: Wisdom Publications.

Gutschow, Kim. 2004. Being a Buddhist Nun: The Struggle for Enlightenment in the Himalayas. Cambridge: Harvard University Press.

Gyatso, Janet. 2003. One Plus One Makes Three: Buddhist Gender, Monasticism, and the Law of the Non-Excluded Middle. History of Religions 43: 89-115. [CrossRef]

Gyatso, Janet. 2010. Female Ordination in Buddhism: Looking into a Crystal Ball, Making a Future. In Dignity and Discipline: Reviving Full Ordination for Buddhist Nuns. Edited by Thea Mohr and Jampa Tsedroen. Boston: Wisdom Publications, pp. 1-21.

Halafoff, Anna, and Praveena Rajkobal. 2015. Sakyadhita International: Gender Equity in Ultramodern Buddhism. Feminist Theology 23: 111-27. [CrossRef] 
Hea, Ai Sim. 2008. Contributions of Buddhist Women in the Malaysian Buddhist Youth Movement. In Buddhist Women in a Global Multicultural Community. Edited by Karma Lekshe Tsomo. Petaling Jaya: Sukhi Hotu Dhamma Publications, pp. 153-59.

Heirman, Ann. 2001. Chinese Nuns and Their Ordination in Fifth Century China. Journal of the International Association of Buddhist Studies 24: 275-304.

$\mathrm{Hu}$, Hsiao-Lan. 2017. The Next Obstacles for Buddhist-Feminist Scholar-Practitioners: Rita Gross's Self-Identities and Legacies. Paper presented at the 15th Sakyadhita International Conference on Buddhist Women, Hong Kong, China, June 22-28.

Hüsken, Ute, and Petra Kieffer-Pülz. 2012. Buddhist Ordination as initiation Ritual and Legal Procedure. In Negotiating Rites. Edited by Ute Hüsken and Frank Neubert. Oxford: Oxford University Press, pp. 255-76.

Jefferey, Patricia. 2001. Agency, Activism, and Agendas. In Women, Gender, Religion: A Reader. Edited by Elizabeth A. Castelli. New York: Palgrave, pp. 465-91. First published 1998.

Kawanami, Hiroko. 2007. The Bhikkhuni Ordination Debate: Global Aspirations, Local Concerns, with Special Emphasis on the Views of the Monastic Community in Burma. Buddhist Studies Review 24: 226-44. [CrossRef]

Koppedrayer, Kay, and Mavis L. Fenn. 2008. Sakyadhita: A Transnational Gathering Place for Buddhist Women. Journal of Global Buddhism 9: 45-79.

Lai, Suat Yen. 2017. Buddhism, Equality, and Feminism: Embodied Practices. Paper presented at the 15th Sakyadhita International Conference on Buddhist Women, Hong Kong, China, June 22-28.

LaMacchia, Linda. 2017. Feminism and the Everyday Lives of Nuns and Monks in Kinnaur. Paper presented at the 15th Sakyadhita International Conference on Buddhist Women, Hong Kong, China, June 22-28.

Langenberg, Amy Paris. 2012. Scarecrows, Upāsakas, Fetuses, and Other Child Monastics in Middle Period Indian Buddhism. In Little Buddhas: Children and Childhood in Buddhist Texts and Traditions. Edited by Vanessa Sasson. New York: Oxford University Press, pp. 43-74.

Letizia, Chiara. 2014. Buddhist Activism, New Sanghas, and the Politics of Belonging in Some Tharu and Magar Communties in Southern Nepal. In Facing Globalization in the Himalayas: Belonging and the Politics of the Self. Edited by Gerard Toffin and Joanna Pfaff-Czamecka. Singapore: Sage Publications, pp. 286-322.

Levine, Sarah. 2016. Dhammawati: President of the Theravada Nuns' Order of Nepal. In Figures of Buddhist Modernity. Edited by Jeffrey Samuels, Justin Thomas McDaniel and Mark Michael Rowe. Honolulu: University of Hawaii Press, pp. 62-65.

Levine, Sarah, and David N. Gellner. 2005. Rebuilding Buddhism: The Theravada Movement in Twentieth-Century Nepal. Cambridge: Harvard University Press.

Mackenzie, Vicki. 1998. Cave in the Snow: Tenzin Palmo's Quest for Enlightenment. New York: Bloomsbury.

Mahmood, Saba. 2005. Politics of Piety: The Islamic Revival and the Feminist Subject. Princeton: Princeton University Press.

McMahan, David L. 2008. The Making of Buddhist Modernism. New York: Oxford University Press.

McNay, Lois. 2015. Agency. In The Oxford Handbook of Feminist Theory. Edited by Lisa Disch and Mary Hawkesworth. New York: Oxford University Press.

Miller, Lama Willa B. 2018. Breaking the Silence on Sexual Misconduct. Lion's Roar, May 19. Available online: https:/ / www.lionsroar.com/breaking-the-silence-on-sexual-misconduct/ (accessed on June 5 2018).

Moallem, Minoo. 2001. Transnationalism, Feminism, and Fundamentalism. In Women, Gender, Religion: A Reader. Edited by Elizabeth A. Castelli. New York: Palgrave, pp. 119-48. First published 1999.

Mohanty, Chandra Talpade. 2003. Feminism without Borders: Decolonizing Theory, Practicing Solidarity. Durham: Duke University Press.

Mohr, Thea, and Jampa Tsedroen. 2010. Dignity and Discipline: Reviving Full Ordination for Buddhist Nuns. Boston: Wisdom Publications.

Mrozik, Susanne. 2009. A Robed Revolution: The Contemporary Buddhist Nun's (Bhikșuṇi) Movement. Religion Compass 3: 360-78. [CrossRef]

Mrozik, Susanne. 2014. We Love Our Nuns': Affective Dimensions of the Sri Lankan Bhikkhunī Revival. Journal of Buddhist Ethics 21: 57-95.

Nyanawati, Bhikkuni. 2008. New Opportunities and Challenges for Buddhist Women in Nepal. In Buddhist Women in a Global Multicultural Community. Edited by Karma Lekshe Tsomo. Petaling Jaya: Sukhi Hotu Dhamma Publications, pp. 165-70.

Ohnuma, Reiko. 2006. Debt to the Mother: A Neglected Aspect of the Founding of the Buddhist Nuns' Order. Journal of the American Academy of Religion 74: 861-901. [CrossRef] 
Park, Pori. 2011. The Establishment of Buddhist Nunneries in Contemporary Korea. In Korean Buddhist Nuns and Laywomen. Edited by Eun-Su Cho. Albany: SUNY Press, pp. 165-82.

Reagon, Bernice Johnson. 1983. Coalition Politics: Turning the Century. In Home Girls: A Black Feminist Anthology. Edited by Barbara Smith. New York: Kitchen Table: Woman of Color Press, pp. 356-58.

Said, Edward. 1978. Orientalism. New York: Pantheon Books.

Salgado, Nirmala S. 2013. Buddhist Nuns and Gendered Practice: In Search of the Female Renunciant. New York: Oxford University Press.

Samuels, Jeffrey. 2017. Contemporary Buddhism in Malaysia. In The Oxford Handbook of Contemporary Buddhism. Edited by Michael Jerryson. New York: Oxford University Press.

Sonam, Wangmo. 2017. Gendered Roles in Buddhist Religious Practices in Bhutan: A Case Study of Two Nunneries. Ph.D. thesis, University of Malaya, Kuala Lumpur, Malaysia.

Sonam, Wangmo, and Karma Tashi Choedron. Forthcoming. Voices of freedom in Bhutan: Reclaiming lost femininity in Vajrayana Buddhism. Kemanusiaan: The Asian Journal of Humanities.

Sonam, Wangmo, and Edo Juli. 2016. Empowerment through Monastic Education: A Case Study of Buddhist Nuns in Bhutan. SARJANA 31: 29-44.

Strong, John. 2008. The Experience of Buddhism: Sources and Interpretations, 3rd ed. Belmont: Wadsworth.

Suh, Sharon. 2008. Roots/Routes: Transmitting the Buddhadharma across time and place: Challenges and implications for Contemporary Buddhist Women. In Buddhist Women in a Global Multicultural Community. Edited by Karma Lekshe Tsomo. Petaling Jaya: Sukhi Hotu Dhamma Publications, pp. 3-9.

Terk, Seet Lee. 2008. Buddhist Nuns in Malaysia. In Buddhist Women in a Global Multicultural Community. Edited by Karma Lekshe Tsomo. Petaling Jaya: Sukhi Hotu Dhamma Publications, pp. 122-28.

Tsomo, Karma Lekshe. 2010. Gender Equity and Human Rights. In Dignity and Discipline: Reviving Full Ordination for Buddhist Nuns. Edited by Thea Mohr and Jampa Tsedroen. Boston: Wisdom Publications, pp. 281-90.

Tsomo, Karma Lekshe. 2015. Book Review: Buddhist Nuns and Gendered Practice: In Search of the Buddhist Renunciant, by Nirmala Salgado. Journal of Global Buddhism 16: 1-7.

(C) 2018 by the author. Licensee MDPI, Basel, Switzerland. This article is an open access article distributed under the terms and conditions of the Creative Commons Attribution (CC BY) license (http://creativecommons.org/licenses/by/4.0/). 